\title{
Response of denitrification genes nirS, nirK, and nos $Z$ to irrigation water quality in a Chinese agricultural soil
}

\author{
Zhi-Feng Zhou • Yuan-Ming Zheng • Ju-Pei Shen • \\ Li-Mei Zhang • Ji-Zheng He
}

Received: 9 December 2010 /Accepted: 1 March 2011 /Published online: 28 May 2011

(C) Springer-Verlag 2011

\begin{abstract}
Purpose Denitrification is an important biochemical process in global nitrogen cycle, with a potent greenhouse gas product $\mathrm{N}_{2} \mathrm{O}$. Wastewater irrigation can result in the changes of soil properties and microbial communities of agricultural soils. The purpose of this study was to examine how the soil denitrification genes responded to different irrigation regimes.

Materials and methods Soil samples were collected from three rural districts of Beijing (China) with three different irrigation regimes: clean groundwater $(\mathrm{CW})$, reclaimed water (RW), and wastewater (WW). The abundance and diversity of three denitrification microbial genes (nirS, $n i r K$, and $n o s Z$ ) were examined by real-time polymerase chain reaction (PCR) and denaturing gradient gel electrophoresis (DGGE) molecular approaches.

Results and discussion The abundance of nirS in the WW treatment was higher than that in the $\mathrm{CW}$ treatment, and no significant difference was found between the RW and CW or WW treatments. The abundance of nirK gene of the RW
\end{abstract}

Responsible editor: Zhihong $\mathrm{Xu}$

Z.-F. Zhou • Y.-M. Zheng · J.-P. Shen • L.-M. Zhang •

J.-Z. He $(\square)$

State Key Laboratory of Urban and Regional Ecology,

Research Center for Eco-Environmental Sciences,

Chinese Academy of Sciences,

Beijing 100085, China

e-mail: jzhe@rcees.ac.cn

Z.-F. Zhou

Graduate University, Chinese Academy of Sciences,

Beijing 100049, China

Z.-F. Zhou

College of Resources and Environment, Southwest University,

Chongqing 400716, China and WW treatments was higher than that of the CW treatment. There was no difference for nos $Z$ gene among the three treatments. Correspondence analysis based on the DGGE profiles showed that there was no obvious difference in the nos $Z$ gene composition, but nir $S$ and nirK genes changed with different irrigation regimes.

Conclusions Irrigation with unclean water sources enhanced the soil $\mathrm{NO}_{3}{ }^{-}$content and changed the abundance and composition of soil denitrifiers, and different functional genes had different responses. Irrigation with unclean water sources increased the abundance of nirK gene and changed the community structures of nirS and nirK genes, while nos $Z$ gene was relatively stable in the soil. These results could be helpful to explore the mechanisms of the variation of denitrification processes under long-term wastewater irrigation and partially explain the reason of more $\mathrm{N}_{2} \mathrm{O}$ output in the field with wastewater irrigation.

Keywords Agricultural soil · Denitrification gene - DGGE · Irrigation water quality $\cdot$ Real-time polymerase chain reaction

\section{Introduction}

Denitrification, an important part of the global nitrogen cycle, is receiving more and more attention because it is one of the primary soil microbial processes leading to the production of nitrous oxide $\left(\mathrm{N}_{2} \mathrm{O}\right)$, a greenhouse gas and natural catalyst of stratospheric ozone degradation. $\mathrm{N}_{2} \mathrm{O}$ concentration in the atmosphere had ascended from 270 to $319 \mathrm{ppb}$, with an increasing rate of about $0.26 \%$ per year from 1750 to 2005 (IPCC 2007), while agricultural fertilization managements were the dominant sources of atmospheric $\mathrm{N}_{2} \mathrm{O}$ (Bouwman 1990). Thus, denitrification, 
as one of the main pathways for the losses of nitrogen $(\mathrm{N})$ fertilizers from agricultural soils, is of interests for both environmental and economic reasons (Enwall et al. 2005).

Denitrification is a biochemical process involving the stepwise reduction of nitrate $\left(\mathrm{NO}_{3}{ }^{-}\right)$and nitrite $\left(\mathrm{NO}_{2}{ }^{-}\right)$to produce the gaseous products of nitric oxide $(\mathrm{NO}), \mathrm{N}_{2} \mathrm{O}$, and dinitrogen $\left(\mathrm{N}_{2}\right)$ under anaerobic conditions. This process is mediated by physiologically diverse groups of microorganisms. The denitrifying bacteria, namely denitrifiers, are known to belong to more than 50 genera (Zumft 1997), and the nitrate-reducing bacteria comprise an even larger group of phylogenetically unrelated microorganisms (Philippot and Hojberg 1999). Therefore, it is difficult to determine the diversity of nitrate-reducing communities using 16S rRNA gene approaches. Fortunately, genes that encode key enzymes (nitrate-, nitrite-, nitric oxide-, and nitrous oxide reductases) in nitrate reduction processes have been established as molecular markers (Smith et al. 2007). These functional genes include nitrite reductase genes (nirS and $\operatorname{nir} K$ ), nitrous oxide reductase gene (nosZ), and nitric oxide reductase gene (nor $B)$.

The abundance and community compositions of the functional genes involved in denitrification can be affected by many factors, such as competition, predation, water content, $\mathrm{pH}, \mathrm{O}_{2}$, and substrate availability (Ladd et al. 1993; Franklin and Mills 2003). Some studies have investigated the responses of denitrifiers to soil environmental changes. Wallenstein (2004) demonstrated that the abundance of nirK and nirS genes in the long-term fertilized plots (with $\left(\mathrm{NH}_{4}\right)_{2} \mathrm{SO}_{4}$ ) was lower than that in the control plots. Wolsing and Prieme (2004) found that fertilization with mineral fertilizer and cattle manure caused a shift in the community structure of denitrifiers in an agricultural soil. More recently, it was reported that organic fertilizers (manure, straw) increased the abundance of both nirK and nirS genes in a tropical agro-ecosystems (Hai et al. 2009). These studies indicated that the abundance and community structure of the soil denitrifiers were influenced by $\mathrm{N}$ availability, carbon availability, moisture, $\mathrm{pH}$, and management practices, and these different functional genes could respond differently to environmental changes.

An increase in water shortages has required more frequent use of reclaimed water (RW) or even wastewater (WW) in agricultural irrigation. RW and WW, as complex mixtures, contained many organic, inorganic compounds, and ions. Irrigation with WW and RW could result in the shift of soil basic characteristics that could influence microbial diversities and functions (Friedel et al. 2000; Mapanda et al. 2005; Qian and Mecham 2005). Previous studies have shown that WW irrigation could increase the rates of denitrification and denitrifying enzyme synthesis in a soil ecosystem (Barton et al. 1999, 2000; Friedel et al. 2000; Zou et al. 2009). However, the responses of soil functional genes involved in denitrification to wastewater irrigation still remain unknown. Thus, in this study, the responses of soil nirS, nirK, and nosZ genes to the different irrigation water sources were investigated based on molecular approaches. The purpose of this study was to examine whether and how these soil functional genes would respond to the long-term and different irrigation regimes. The results would be helpful to improve understanding of the relationships between functional genes of denitrifiers and the denitrification process in the agricultural soil ecosystems.

\section{Materials and methods}

\subsection{Site description and soil sampling}

Beijing, the capital of China, is confronted with serious deficiency of water resources. Since 1960s, wastewater (domestic sewage) irrigation has been commenced in agricultural area of Tongzhou District (Yang et al. 2005). In recent years, reclaimed water (treated domestic sewage) has been widely used as an important resource in Beijing. By 2007, about 0.5 billion $\mathrm{m}^{3}$ reclaimed water was in recycle, including agricultural use that mainly located in southern suburb of the city, namely Daxing District (Cong and Zhao 2009). A reclaimed water (from Xiaohongmen and Huangcun sewage treatment plants) recycling demonstration has been constructed in this area since 2004 .

In this study, soil samples were collected from two sites in Daxing (reclaimed water irrigation, RW) and Tongzhou (wastewater irrigation, WW), respectively (Fig. 1). In addition, one site in Changping District was chosen as control (clean water irrigation, $\mathrm{CW}$ ). The soils in these three sites belonged to the same soil type classified as Eutric Cambisols and had very similar background characteristics before irrigation. All three sites had an annual wheat-maize rotation system and similar agricultural management practices (Zheng et al. 2008).

In each site, 12 surface soils $(0-20 \mathrm{~cm})$ were collected randomly in an area of $100 \mathrm{~m}^{2}$, and then mixed thoroughly to form one representative sample. Three samples were collected in each site as replicates. Soil samples were kept in an ice box and taken back to the laboratory, and then ground to pass through a $2-\mathrm{mm}$ sieve and stored at $-80^{\circ} \mathrm{C}$ for DNA extraction.

\subsection{Determination of soil basic properties and DNA extraction}

Soil $\mathrm{pH}$ was determined with a soil to water ratio of 2:5. Soil organic matter was measured using the $\mathrm{K}_{2} \mathrm{Cr}_{2} \mathrm{O}_{7}$ oxidation method. Soil nitrate and ammonium were 


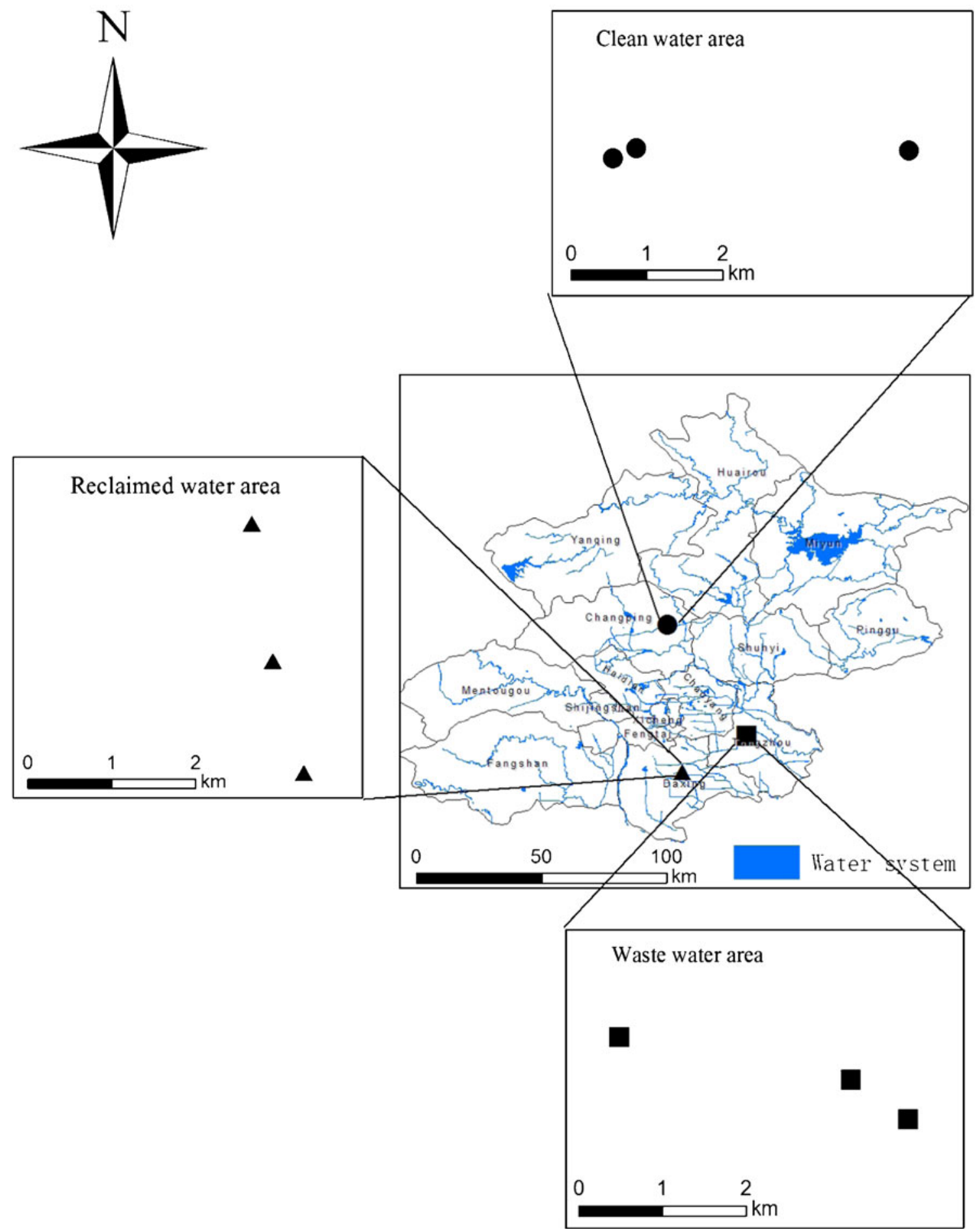

Fig. 1 Map showing the location of the sampling sites under different irrigation regimes

extracted with $2 \mathrm{~mol} / \mathrm{L} \mathrm{KCl}$ and determined by a Continuous Flow Analyzer (SAN++, Skalar, Holland).

Soil DNA was extracted from $0.5 \mathrm{~g}$ fresh soil using MoBio UltraClean ${ }^{\mathrm{TM}}$ soil DNA isolation Kits (San Diego, CA, USA) according to the manufacturer's protocol with previously described modification (He et al. 2007).

\subsection{Real-time polymerase chain reaction assay}

Real-time polymerase chain reaction (PCR) was performed on an iCycler iQ5 thermocycler (Bio-Rad, USA). Amplification was performed in $25-\mu \mathrm{L}$ reaction mixtures by using SYBR $^{\circledR}$ Premix Ex Taq ${ }^{\text {TM }}$ as 
described by the suppliers (Takara Bio, Otsu, Shiga, Japan). The DNA extracts were diluted fivefold and used as template with a final content of $1-10 \mathrm{ng}$ in each reaction mixture. The primers and procedures used to amplify each target gene in real-time PCR were listed in Table 1. Data analysis was carried out with iCycler software (version 1.0.1384.0 CR). The parameter $\mathrm{Ct}$ (threshold cycle) was determined as the cycle number at which a statistically significant increase in the reporter fluorescence was detected.

Standard curves for real-time PCR assays were developed as described previously (He et al. 2007). Briefly, the nirS, nirK, and nosZ genes were PCR-amplified from extracted DNA with the primers listed in Table 1, and then, the PCR products were cloned into the pGEM-T Easy Vector (Promega Madison, USA). Plasmids used as standards for quantitative analyses were extracted from the correct insert clones of each target gene. The concentration of plasmid DNA was determined on a Nanodrop ${ }^{\circledR}$ ND-1000 UV-vis Spectrophotometer (NanoDrop Technologies, USA), and then, the copy numbers of target genes were calculated. Tenfold serial dilutions of a known copy number of the plasmid DNA were subjected to real-time PCR assay in triplicate to generate an external standard curve.

2.4 PCR amplification and denaturing gradient gel electrophoresis analysis

For denaturing gradient gel electrophoresis (DGGE) analysis, the amplification was performed in $50-\mu \mathrm{L}$ reaction mixtures including $1 \times$ PCR buffer, $400 \mu \mathrm{mol} / \mathrm{L}$ each $\mathrm{dNTP}$, 2.5 U hot star Taq DNA polymerase (Takara Bio, Otsu, Shiga, Japan) plus primers (Table 1).

DGGE analysis of each PCR product was performed with the DCode Universal Mutation Detection System (Bio-Rad Laboratories, Hercules, USA). PCR products of $\operatorname{nir} S$, nirK, and nos $Z$ genes were loaded onto $6 \%(w / v)$ polyacrylamide (37.5:1, acrylamide:bisacrylamide) gels with a denaturing gradient of $50-75 \%, 40-65 \%$, and 50 $70 \%$ (100\% denaturant contains $7 \mathrm{~mol} / \mathrm{L}$ urea and $40 \%(v /$ $v$ ) formamide), respectively. Electrophoreses were run at the temperature of $60^{\circ} \mathrm{C}$ and $100 \mathrm{~V}$ for $15 \mathrm{~h}, 12 \mathrm{~h}$, and $15 \mathrm{~h}$ for nirK, nirS, and nos $Z$ genes, respectively. The gels were stained for $30 \mathrm{~min}$ according to the manufacturer's (Invitrogen 20 Molecular Probes, Eugene, USA) instructions, scanned by a GBOX/HR-E-M (Gene Company Limited, Syngene, UK). The obtained results were analyzed using Quantity One Software. The Shannon diversity index $(H)$ and Evenness index $(E)$ were used to calculate the band pattern diversity of nir $S$, nirK, and nos $Z$ genes based on the following equations:

$H=-\sum_{i=1}^{S} p i \ln p i=-\sum_{i=1}^{S}(N i / N) \ln (N i / N)$

$E=H / H \max =H / \ln S$

where $N i$ is the abundance of the $i$ th ribotype, $N$ is the total abundance of all ribotypes in the sample (lane of DGGE gels), and $S$ is the number of ribotypes.

Table 1 Primer sets and PCR profiles used for the real-time PCR and DGGE

\begin{tabular}{|c|c|c|c|c|}
\hline $\begin{array}{l}\text { Target } \\
\text { gene }\end{array}$ & Primer set & Sequence $\left(5^{\prime}-3^{\prime}\right)$ & Thermal profile & Reference \\
\hline \multirow[t]{2}{*}{$\operatorname{nir} S$} & $\mathrm{~cd} 3 \mathrm{aF}$ & GTSAACGTSAAGGARACSGG & $\begin{array}{l}\text { q-PCR: } 94^{\circ} \mathrm{C} / 2 \mathrm{~m} ; 6 \text { cycles of } 94^{\circ} \mathrm{C} / 30 \mathrm{~s}, 57^{\circ} \mathrm{C} / 30 \mathrm{~s} \\
\left(-1^{\circ} \mathrm{C} / \mathrm{cycle}\right), 72^{\circ} \mathrm{C} / 45 \mathrm{~s} ; 30 \text { cycles of } 94^{\circ} \mathrm{C} / 30 \mathrm{~s}, \\
52^{\circ} \mathrm{C} / 30 \mathrm{~s}, 72^{\circ} \mathrm{C} / 45 \mathrm{~s} .\end{array}$ & (Michotey et al. 2000) \\
\hline & $\mathrm{R} 3 \mathrm{~cd} \mathrm{R} 3 \mathrm{~cd}-\mathrm{GC}^{\mathrm{a}}$ & GASTTCGGRTGSGTCTTGA & $\begin{array}{l}\text { DGGE: } 94^{\circ} \mathrm{C} / 2 \mathrm{~m} ; 10 \text { cycles of } 94^{\circ} \mathrm{C} / 30 \mathrm{~s}, 57^{\circ} \mathrm{C} / 30 \mathrm{~s} \\
\left(-0.5^{\circ} \mathrm{C} / \text { cycle }\right), 72^{\circ} \mathrm{C} / 45 \mathrm{~s} ; 30 \text { cycles of } 94^{\circ} \mathrm{C} / 30 \mathrm{~s}, \\
52^{\circ} \mathrm{C} / 30 \mathrm{~s}, 72^{\circ} \mathrm{C} / 45 \mathrm{~s} ; 72^{\circ} \mathrm{C} / 10 \mathrm{~m} .\end{array}$ & $\begin{array}{l}\text { (Braker and Tiedje } \\
\text { 2003) }\end{array}$ \\
\hline \multirow[t]{2}{*}{$\operatorname{nirK}$} & $\mathrm{F} 1 \mathrm{aCu}$ & ATCATGGTSCTGCCGCG & $\begin{array}{l}\text { q-PCR: } 95^{\circ} \mathrm{C} / 3 \mathrm{~m} ; 6 \text { cycles of } 95^{\circ} \mathrm{C} / 30 \mathrm{~s}, 63^{\circ} \mathrm{C} / 30 \mathrm{~s} \\
\left(-1{ }^{\circ} \mathrm{C} / \text { cycle }\right), 72^{\circ} \mathrm{C} / 30 \mathrm{~s} ; 32 \text { cycles of } 95^{\circ} \mathrm{C} / 30 \mathrm{~s} \\
58^{\circ} \mathrm{C} / 30 \mathrm{~s}, 72^{\circ} \mathrm{C} / 30 \mathrm{~s} \text {. }\end{array}$ & $\begin{array}{l}\text { (Hallin and Lindgren } \\
\text { 1999) }\end{array}$ \\
\hline & $\mathrm{R} 3 \mathrm{Cu} \mathrm{R} 3 \mathrm{Cu}-\mathrm{GC}^{\mathrm{a}}$ & GCCTCGATCAGRTTGTGGTT & $\begin{array}{l}\text { DGGE: } 95^{\circ} \mathrm{C} / 3 \mathrm{~m} ; 32 \text { cycles of } 95^{\circ} \mathrm{C} / 30 \mathrm{~s}, 58^{\circ} \mathrm{C} / 30 \mathrm{~s} \\
\text { and } 72^{\circ} \mathrm{C} / 45 \mathrm{~s} ; 72^{\circ} \mathrm{C} / 10 \mathrm{~m} .\end{array}$ & $\begin{array}{l}\text { (Hallin and Lindgren } \\
\text { 1999) }\end{array}$ \\
\hline \multirow[t]{2}{*}{$\operatorname{nos} Z$} & nosZ-F & CGYTGTTCMTCGACAGCCAG & $\begin{array}{l}\text { q-PCR: } 94^{\circ} \mathrm{C} / 2 \mathrm{~m} ; 6 \text { cycles of } 94^{\circ} \mathrm{C} / 30 \mathrm{~s}, 57^{\circ} \mathrm{C} / 30 \mathrm{~s} \\
\left(-1^{\circ} \mathrm{C} / \text { cycle }\right), 72^{\circ} \mathrm{C} / 45 \mathrm{~s} ; 30 \text { cycles of } 94^{\circ} \mathrm{C} / 30 \mathrm{~s}, \\
52^{\circ} \mathrm{C} / 30 \mathrm{~s}, 72^{\circ} \mathrm{C} / 45 \mathrm{~s} .\end{array}$ & (Kloos et al. 2001) \\
\hline & $\begin{array}{l}\operatorname{nosZ1662R} \\
\operatorname{nosZ1662R-GC}{ }^{\mathrm{a}}\end{array}$ & CGSACCTTSTTGCCSTYGCG & $\begin{array}{l}\text { DGGE: } 94^{\circ} \mathrm{C} / 2 \mathrm{~m}, 10 \text { cycles of } 94^{\circ} \mathrm{C} / 30 \mathrm{~s}, 58^{\circ} \mathrm{C} / 30 \mathrm{~s} \\
\left(-0.5^{\circ} \mathrm{C} / \text { cycle }\right), 72^{\circ} \mathrm{C} / 60 \mathrm{~s} ; 30 \text { cycles of } 94^{\circ} \mathrm{C} / 30 \mathrm{~s}, \\
53^{\circ} \mathrm{C} / 30 \mathrm{~s}, 72^{\circ} \mathrm{C} / 60 \mathrm{~s} ; 72^{\circ} \mathrm{C} / 10 \mathrm{~m} .\end{array}$ & (Throback et al. 2004) \\
\hline
\end{tabular}

${ }^{\mathrm{a}}$ (GGCGGCGCGCCGCCCGCCCCGCCCCCGTCGCCC) was attached to the $5^{\prime}$ end of the primers 
Table 2 Basic properties of the soil under different irrigation regimes

\begin{tabular}{lcccc}
\hline Treatment & $\mathrm{pH}\left(\mathrm{H}_{2} \mathrm{O}\right)$ & Organic matter $(\mathrm{g} / \mathrm{kg})$ & $\mathrm{NO}_{3}{ }^{-}(\mathrm{mg} / \mathrm{kg})$ & $\mathrm{NH}{ }^{+}(\mathrm{mg} / \mathrm{kg})$ \\
\hline $\mathrm{CW}$ & $7.70 \pm 0.05 \mathrm{a}$ & $19.9 \pm 3.2 \mathrm{a}$ & $22.9 \pm 1.6 \mathrm{a}$ & $8.6 \pm 0.5 \mathrm{a}$ \\
$\mathrm{RW}$ & $7.74 \pm 0.12 \mathrm{a}$ & $20.6 \pm 2.0 \mathrm{a}$ & $34.1 \pm 3.0 \mathrm{~b}$ & $8.4 \pm 0.2 \mathrm{ab}$ \\
$\mathrm{WW}$ & $7.74 \pm 0.10 \mathrm{a}$ & $23.4 \pm 3.9 \mathrm{a}$ & $44.7 \pm 1.1 \mathrm{c}$ & $7.5 \pm 0.5 \mathrm{~b}$ \\
\hline
\end{tabular}

$C W$ clean water irrigated, $R W$ reclaimed water irrigated, $W W$ wastewater irrigated

All values are mean $\pm \mathrm{SD}(n=3)$. The different letters $(\mathrm{a}-\mathrm{c})$ within the same column indicate significant differences between treatments at $P<0.05$

\subsection{Data analysis}

One-way analysis of variance (ANOVA) followed by S-NK-test was performed using SPSS 11.5 to check for quantitative differences between samples. $P<0.05$ was considered to be statistically significant. Correspondence analysis (CA) for community ordination was conducted using CANOCO 4.5 for Windows using relative band intensity data obtained from the Quantity One analysis.

\section{Results}

\subsection{Soil basic properties}

Soil basic properties are shown in Table 2. There were no significant differences for the soil $\mathrm{pH}$ and organic matter between soil samples from the $\mathrm{CW}, \mathrm{RW}$, and $\mathrm{WW}$ treatments. Significant differences $(P<0.05)$ were detected between $\mathrm{NO}_{3}{ }^{-}$contents of soil samples from different sites with an order for the treatments of WW $>\mathrm{RW}>\mathrm{CW}$. The content of soil $\mathrm{NH}_{4}^{+}$in the $\mathrm{CW}$ site was significantly higher than that of the WW site $(P<0.05)$.

\subsection{Abundances of nirS, nirK, and nos Z genes}

The abundances of nirS, nirK, and nosZ genes of the soil samples are shown in Fig. 2. The copy numbers of nirS gene in the soil samples of the CW, RW, and WW treatments were $1.35 \times 10^{7}, 1.93 \times 10^{7}$, and $2.49 \times 10^{7}$ copies $\mathrm{g}^{-1}$ dry soil, respectively. The $\operatorname{nir} S$ abundance of the WW treatment was significantly higher than that of the $\mathrm{CW}$ treatment $(P<0.05)$, and no significant variation was observed between the RW and the other two treatments. The copy numbers of nirK gene ranged from $5.24 \times 10^{7}$ to $1.78 \times 10^{8}$ copies $\mathrm{g}^{-1}$ dry soil. The nirK abundances of the WW and RW treatments were significantly higher than that of the $\mathrm{CW}$ treatment $(P<0.05)$, and no significant difference was found between the RW and WW treatments. The nos $Z$ gene copy numbers in those soil samples ranged from $4.53 \times 10^{8}$ to $7.17 \times 10^{8}$ copies $\mathrm{g}^{-1}$ dry soil, and no significant differences were observed among the $\mathrm{CW}, \mathrm{RW}$, and WW treatments.

\subsection{DGGE fingerprints of nirS, nirK, and nos $Z$ genes}

The community structures of nir $S$, nirK, and nos $Z$ genes were analyzed by DGGE (Figs. 3a, 4a, and 5a). DGGE profiles with two replicates for each soil sample indicated good reproducibility. High diversities were shown in the DGGE profiles of nirS, nirK, and nosZ genes. For nirS and $\operatorname{nirK}$, there were obvious variations between soil samples from the three sites (Figs. 3a and 4a). All the samples of the $\mathrm{CW}$ treatments showed less bands and lower diversity than those of the RW and WW treatments. The CA ordination diagram based on the DGGE patterns showed that nirS and nirK communities from the RW and WW treatments had relatively similar structures, and were obviously different from the CW treatment (Figs. $3 b$ and $4 b$ ). Furthermore, the nirK Shannon values of the RW and WW treatments were significantly higher than that of the $\mathrm{CW}$ treatment (Table 3). The DGGE profile of nos $Z$ showed minor variations between soil samples (Fig. 5a), and the scattered CA ordination diagram ascertained little difference in the nos $Z$ gene communities between treatments (Fig. 5b). The Shannon values of nirS, nirK, and nosZ genes are listed in Table 3. For nirS and nos $Z$ genes, there was no

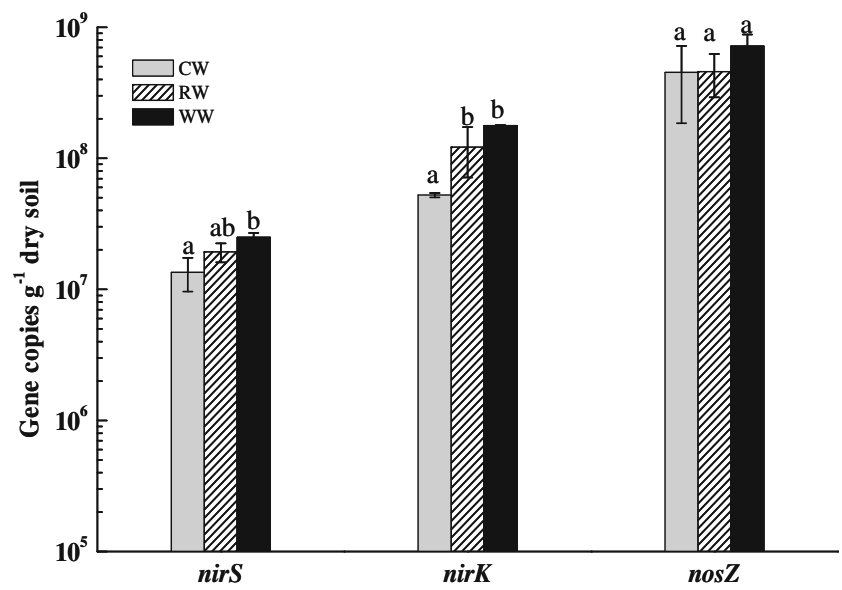

Fig. 2 Abundances of nirS, nirK, and nos $Z$ genes in the soils under different irrigation regimes of clean groundwater irrigated $(C W)$, reclaimed water irrigated $(R W)$, and wastewater irrigated $(W W)$ samples. Error bars indicate standard deviations $(n=3)$. The different letters indicate significant differences $(P<0.05)$ 
Fig. 3 a DGGE profile of nirS gene in the soils under different irrigation regimes of clean groundwater irrigated $(\mathrm{CW})$, reclaimed water irrigated $(R W)$, and wastewater irrigated $(W W)$ samples. b Correspondence analysis (CA) ordination diagram of nirS gene communities generated by the nirS DGGE banding patterns

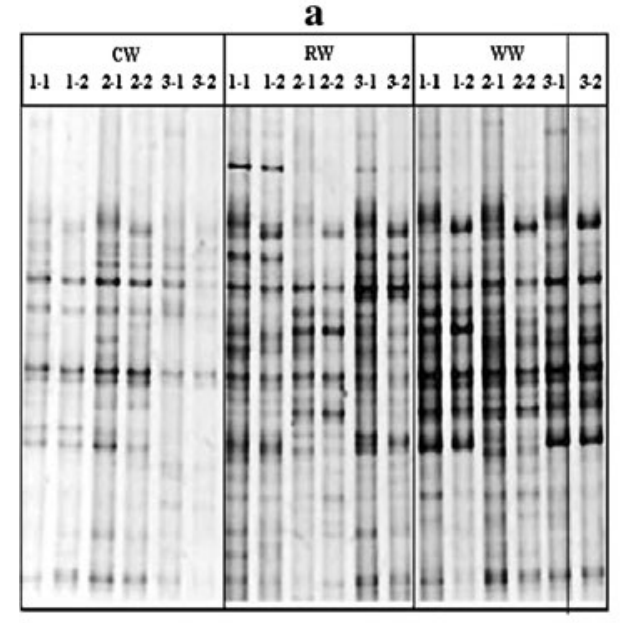

b

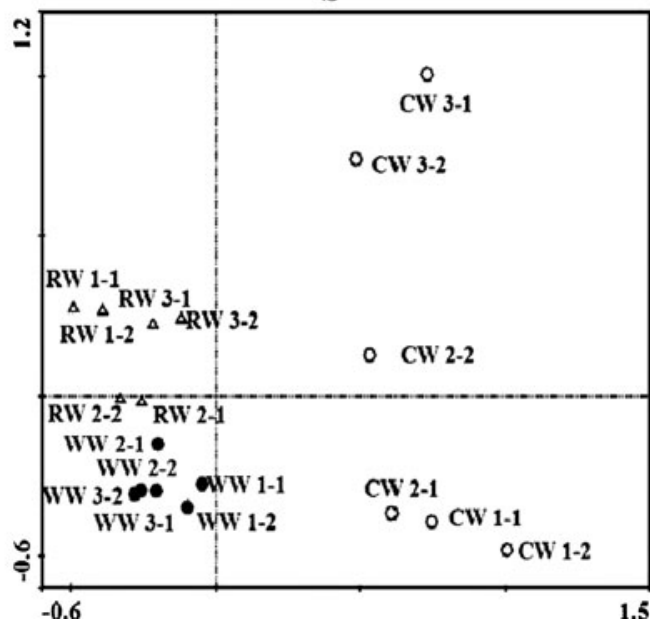

difference in the Shannon values among the CW, RW, and WW treatments. For nirK gene, the Shannon values of the RW and WW treatments were higher than that of the CW treatment $(P<0.05)$.

\section{Discussion}

4.1 Abundances of nirS, nirK, and nosZ genes under different irrigation regimes

In this study, there was lower nirS gene abundance than nirK in all samples, which was consistent with some previous studies (Hai et al. 2009; Yoshida et al. 2009). The abundance of nos $Z$ gene was the highest one among the three functional genes in this study. This result was higher than those of previously reported: $\operatorname{nos} Z$ density of $3 \times 10^{6}-2.8 \times 10^{8}$ copies $g^{-1}$ dry soil (Kandeler et al. 2006;

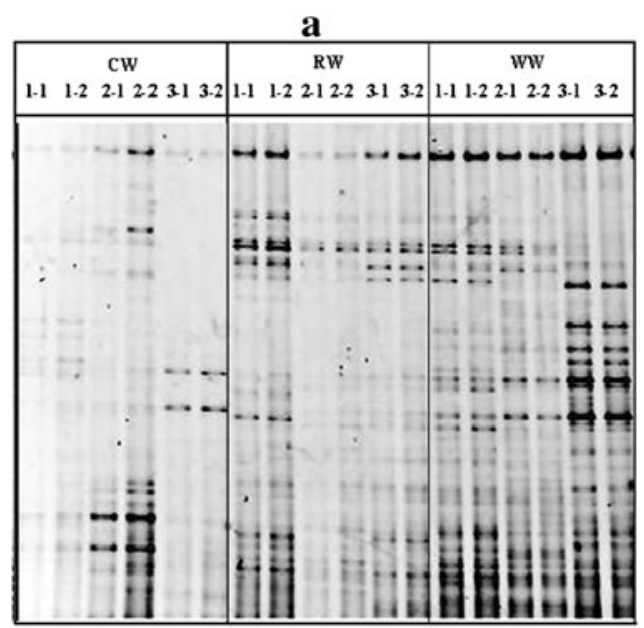

Fig. 4 a DGGE profile of nirK gene in the soils under different irrigation regimes of clean groundwater irrigated $(\mathrm{CW})$, reclaimed water irrigated $(R W)$, and wastewater irrigated $(W W)$ samples. b
Dandie et al. 2008; Hallin et al. 2009). But Chronakova et al. (2009) found the nos $Z$ gene copy number was in a range of $9.1 \times 10^{7}-7.5 \times 10^{9}$ copies $\mathrm{g}^{-1}$ soil in an upland pasture soil. Henry et al. (2006) found there was no significant difference between the abundances of nos $Z$ and nirK in an agricultural soil of France. Thus, the abundances of soil nirS, nirK, and nos Z genes might be closely related to the properties of soil samples, especially when the management practices were different.

Although the copy numbers of nirK gene increased as a result of irrigation with wastewater and reclaimed water, no difference was found in the copy numbers of nirS gene between the $\mathrm{CW}$ and RW treatments. This result indicated that soil nirK was more sensitive with the water source quality than nirS gene, which brought more in line with the result of Yoshida et al. (2010), who found that the nirK gene were more sensitive than $\operatorname{nir} S$ gene in a paddy soil to management practices. No significant difference was found

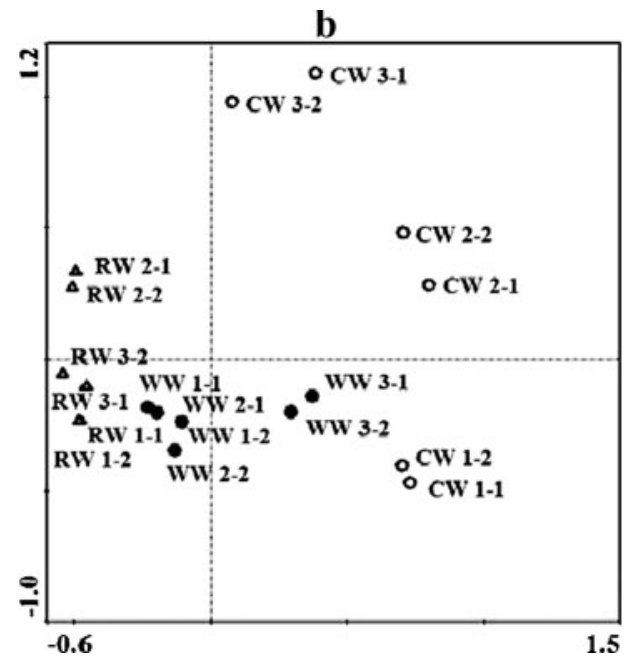

Correspondence analysis (CA) ordination diagram of nirK gene communities generated by the nirK DGGE banding patterns 
Fig. 5 a DGGE profile of nos $Z$ gene in the soils under different irrigation regimes of clean groundwater irrigated $(\mathrm{CW})$, reclaimed water irrigated $(R W)$, and wastewater irrigated $(W W)$ samples. b Correspondence analysis (CA) ordination diagram of $n o s Z$ gene communities generated by the nos $Z$ DGGE banding patterns
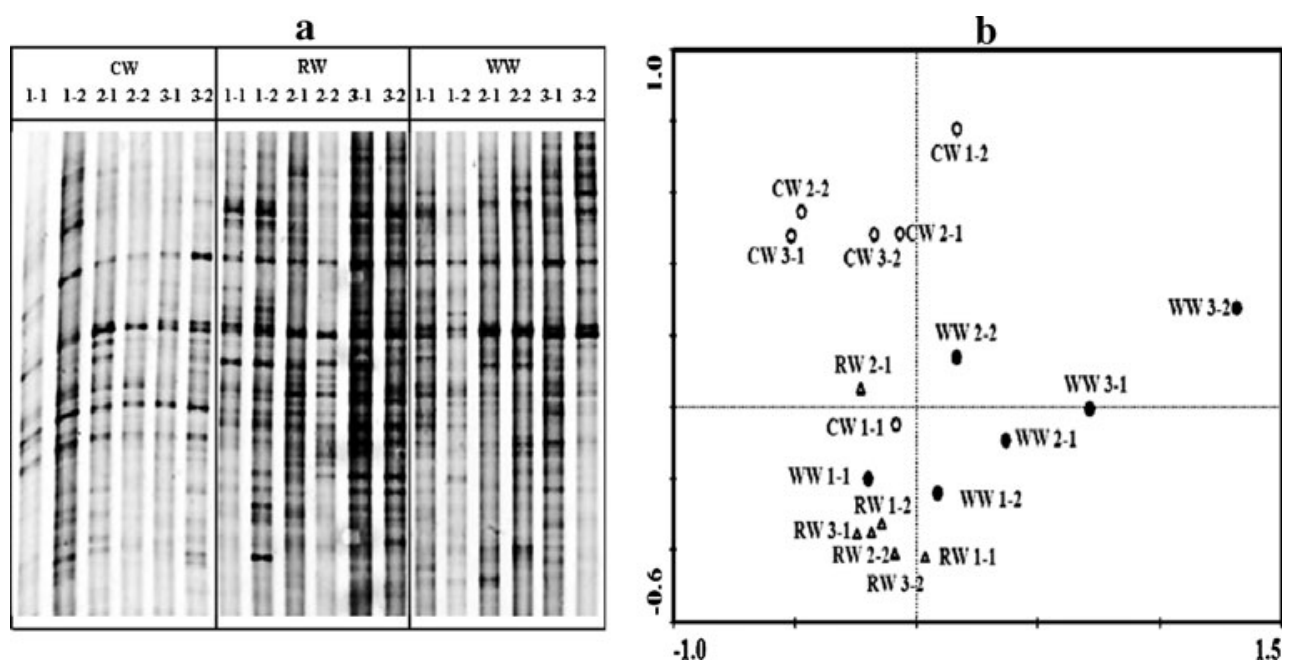

about the nos $Z$ gene copy numbers between soil samples. All these results hereby indicated that the functional genes involved in denitrification had different responses to the changes of environment.

Environmental factors affected the abundance of the bacterial denitrification genes greatly (Kandeler et al. 2006; Yoshida et al. 2009). Significantly positive correlations between the soil $\mathrm{NO}_{3}{ }^{-}$and the quantity of nirK gene $(R=0.682, P<0.05)$, and between the soil organic matter content and the quantity of nirS gene $(R=0.614, P<0.05)$, were found in this study. This result could imply that $\mathrm{NO}_{3}{ }^{-}$ and organic matters, as the important substrates for the growth of soil denitrifiers, could stimulate soil denitrifiers. The abundances of soil denitrifiers were closely related to the basic properties of the soil samples, which were influenced by irrigated water greatly in this study.

4.2 Composition and diversity of soil nirS, nirK, and nos $Z$ genes under different irrigation regimes

CA analysis based on the DGGE profiles showed that the composition of nirS and nirK genes was affected greatly by irrigated water, as well as the copy number of functional genes. However, the community structures of nos $Z$ were relatively stable under different irrigation regimes in this soil. The "unclean" water irrigation might have selective constraints on soil nirS and nirK communities. Furthermore, the higher nirK Shannon values of the RW and WW treatments compared with the $\mathrm{CW}$ further confirmed that nirK might be more sensitive than nirS gene. Some other studies also found the similar phenomena in different soil or under different environmental conditions. For example, Yoshida et al. (2010) found that nirK was more sensitive than nirS gene to denitrification-inducing conditions (additions of nitrate and organic matters) in a rice paddy soil; Djigal et al. (2010) found that bacterial-feeding nematodes decreased the copy numbers of soil nirS and nirK genes, but only the nirK community was obviously affected by the nematode feeding.

In our study, no obvious difference was found for nos $Z$ gene under the different irrigation regimes. Combined with the soil basic properties, this result indicated that nos $Z$ gene should be relatively stable under different irrigation regimes and less sensitive to higher nitrate content in this soil.

\section{Conclusions and perspectives}

This study demonstrated that soil functional genes involved in the denitrification processes responded differently to

Table 3 Shannon and Evenness values of nirS, nirK, and nos $Z$ genes

\begin{tabular}{|c|c|c|c|c|c|c|}
\hline \multirow[t]{2}{*}{ Treatment } & \multicolumn{2}{|l|}{$n i r S$} & \multicolumn{2}{|l|}{ nirk } & \multicolumn{2}{|l|}{$\operatorname{nos} Z$} \\
\hline & Shannon & Evenness & Shannon & Evenness & Shannon & Evenness \\
\hline $\mathrm{CW}$ & $2.55 \pm 0.20 \mathrm{a}$ & $0.988 \pm 0.005$ & $2.58 \pm 0.22 \mathrm{a}$ & $0.987 \pm 0.013$ & $2.70 \pm 0.08 \mathrm{a}$ & $0.965 \pm 0.004$ \\
\hline RW & $2.87 \pm 0.14 \mathrm{a}$ & $0.983 \pm 0.006$ & $3.05 \pm 0.05 \mathrm{~b}$ & $0.984 \pm 0.012$ & $2.89 \pm 0.14 \mathrm{a}$ & $0.956 \pm 0.018$ \\
\hline WW & $2.77 \pm 0.12 \mathrm{a}$ & $0.959 \pm 0.003$ & $3.21 \pm 0.06 \mathrm{~b}$ & $0.971 \pm 0.006$ & $2.78 \pm 0.23 \mathrm{a}$ & $0.962 \pm 0.010$ \\
\hline
\end{tabular}

$C W$ clean water irrigated, $R W$ reclaimed water irrigated, $W W$ wastewater irrigated

All values are mean $\pm \mathrm{SD}(n=3)$. The different letters (a-b) within the same column indicate significant differences between treatments at $P<0.05$ 
environmental changes. Wastewater irrigation increased the abundance and changed the community compositions of the soil nirS and nirK genes. Compared with the direct wastewater irrigation, reclaimed water irrigation only had greater effect on the soil nirK gene. If the abundance of denitrifiers had some relationships with the soil denitrification enzyme activity, the increase of nirK gene copy numbers with a relative constant abundance of nos $Z$ gene under "unclean" water irrigation might be supposed to increase the output of $\mathrm{N}_{2} \mathrm{O}$. This result partially explained the reason of more $\mathrm{N}_{2} \mathrm{O}$ output in the field with wastewater irrigation, although the mechanism is still unclear.

There are some arguments about the relationship between the abundance of denitrifiers and the soil denitrification activity. In the future, the relative rations of those functional genes involved in denitrification should be an important aspect. We need to understand if there is any relationship between the relative rations and the outputs of products within the soil denitrification processes, and how the rations change under different environmental conditions. Another important aspect is the study of the community composition of soil denitrifiers. At present, it is difficult to accurately determine the community composition of soil denitrifiers because of their high diversity. Some new and effective methods, e.g., high-throughput sequencing techniques, should be applied in this aspect. The improved understanding of these two questions will shed light on the relationships between the abundances, community compositions of soil denitrifiers, and their soil ecological functions.

Acknowledgments This work was supported by the Ministry of Sciences and Technology (2009AA06Z402), the Chinese Academy of Sciences (KZCX1-YW-06-03, KSCX2-YW-G072) and the Natural Science Foundation of China (41090281, 41025004, 50921064).

\section{References}

Barton L, McLay CDA, Schipper LA, Smith CT (1999) Denitrification rates in a wastewater-irrigated forest soil in New Zealand. J Environ Qual 28(6):2008-2014

Barton L, Schipper LA, Smith CT, McLay CDA (2000) Denitrification enzyme activity is limited by soil aeration in a wastewater irrigated forest soil. Biol Fertil Soils 32(5):385-389

Bouwman AF (1990) Exchange of greenhouse gases between terrestrial ecosystems and the atmosphere. In: Bouwman AF (ed) Soils and the greenhouse effect. Wiley, Chichester, pp 100-120

Braker G, Tiedje JM (2003) Nitric oxide reductase (norB) genes from pure cultures and environmental samples. Appl Environ Microbiol 69(6):3476-3483

Chronakova A, Radl V, Cuhel J, Simek M, Elhottova D, Engel M, Schloter M (2009) Overwintering management on upland pasture causes shifts in an abundance of denitrifying microbial communities, their activity and $\mathrm{N}_{2} \mathrm{O}$-reducing ability. Soil Biol Biochem 41(6):1132-1138
Cong XH, Zhao YF (2009) Recycle and usage of reclaimed water in Beijing City. Beijing Water Utilities 1:10-12

Dandie CE, Burton DL, Zebarth BJ, Henderson SL, Trevors JT, Goyer C (2008) Changes in bacterial denitrifier community abundance over time in an agricultural field and their relationship with denitrification activity. Appl Environ Microbiol 74(19):59976005

Djigal D, Baudoin E, Plilippot L, Brauman A, Villenave C (2010) Shifts in size, genetic structure and activity of the soil denitrifier community by nematode grazing. Eur J Soil Biol 46(2):112-118

Enwall K, Philippot L, Hallin S (2005) Activity and composition of the denitrifying bacterial community respond differently to long-term fertilization. Appl Environ Microbiol 71(12):83358343

Franklin RB, Mills AL (2003) Multi-scale variation in spatial heterogeneity for microbial community structure in an eastern Virginia agricultural field. FEMS Microbiol Ecol 44(3):335-346

Friedel JK, Langer T, Siebe C, Stahr K (2000) Effects of long-term waste water irrigation on soil organic matter, soil microbial biomass and its activities in central Mexico. Biol Fertil Soils 31 (5):414-421

Hai B, Diallo NH, Sall S, Haesler F, Schauss K, Bonzi M, Assigbetse K, Chotte JL, Munch JC, Schloter M (2009) Quantification of key genes steering the microbial nitrogen cycle in the rhizosphere of sorghum cultivars in tropical agroecosystems. Appl Environ Microbiol 75(15):4993-5000

Hallin S, Lindgren PE (1999) PCR detection of genes encoding nitrile reductase in denitrifying bacteria. Appl Environ Microbiol 65 (4):1652-1657

Hallin S, Jones CM, Schloter M, Philippot L (2009) Relationship between $\mathrm{N}$-cycling communities and ecosystem functioning in a 50-year-old fertilization experiment. ISME J 3(5):597-605

He JZ, Shen JP, Zhang LM, Zhu YG, Zheng YM, Xu MG, Di HJ (2007) Quantitative analyses of the abundance and composition of ammonia-oxidizing bacteria and ammonia-oxidizing archaea of a Chinese upland red soil under long-term fertilization practices. Environ Microbiol 9(9):2364-2374

Henry S, Bru D, Stres B, Hallet S, Philippot L (2006) Quantitative detection of the nos $Z$ gene, encoding nitrous oxide reductase, and comparison of the abundances of $16 \mathrm{~S}$ rRNA, $\operatorname{nar} G$, nirK, and nosZ genes in soils. Appl Environ Microbiol 72(8):5181-5189

Intergovernmental Panel on Climate Change (IPCC) (2007) Climate Change 2007: The Physical Science Basis. Working Group I Contribution to the Fourth Assessment Report of the Intergovernmental Panel on Climate Change. Solomon et al. (eds). Cambridge University Press, Cambridge

Kandeler E, Deiglmayr K, Tscherko D, Bru D, Philippot L (2006) Abundance of narG, nirS, nirK, and nosZ genes of denitrifying bacteria during primary successions of a glacier foreland. Appl Environ Microbiol 72(9):5957-5962

Kloos K, Mergel A, Rosch C, Bothe H (2001) Denitrification within the genus Azospirillum and other associative bacteria. Aust J Plant Physiol 28(9):991-998

Ladd JN, Foster RC, Skjemstad JO (1993) Soil structure-carbon and nitrogen-metabolism. Geoderma 56(1-4):401-434

Mapanda F, Mangwayana EN, Nyamangara J, Giller KE (2005) The effect of long-term irrigation using wastewater on heavy metal contents of soils under vegetables in Harare, Zimbabwe. Agric Ecosyst Environ 107(2-3):151-165

Michotey V, Mejean V, Bonin P (2000) Comparison of methods for quantification of cytochrome cd(1)-denitrifying bacteria in environmental marine samples. Appl Environ Microbiol 66 (4):1564-1571

Philippot L, Hojberg O (1999) Dissimilatory nitrate reductases in bacteria. Biochim Et Biophys Acta Gene Struct Expr 1446 $(1-2): 1-23$ 
Qian YL, Mecham B (2005) Long-term effects of recycled wastewater irrigation on soil chemical properties on golf course fairways. Agron J 97(3):717-721

Smith CJ, Nedwell DB, Dong LF, Osborn AM (2007) Diversity and abundance of nitrate reductase genes ( $\operatorname{nar} G$ and napA), nitrite reductase genes (nirS and $n r f A$ ), and their transcripts in estuarine sediments. Appl Environ Microbiol 73(11):3612-3622

Throback IN, Enwall K, Jarvis A, Hallin S (2004) Reassessing PCR primers targeting nirS, nirK and nos $Z$ genes for community surveys of denitrifying bacteria with DGGE. FEMS Microbiol Ecol 49(3):401-417

Wallenstein MD (2004) Effects of increased nitrogen deposition on forest soil nitrogen cycling and microbial community structure. Duke University, Durham

Wolsing M, Prieme A (2004) Observation of high seasonal variation in community structure of denitrifying bacteria in arable soil receiving artificial fertilizer and cattle manure by determining T-RFLP of nir gene fragments. FEMS Microbiol Ecol 48(2):261-271
Yang J, Zheng YM, Chen TB, Huang ZC, Luo JF, Liu HL, Wu WY, Chen YC (2005) Accumulation and temporal variation of heavy metals in the soils from the Liangfeng Irrigated Area of Tongzhou, Beijing City. Acta Scientiae Circumstantiae 25(9):1175-1181

Yoshida M, Ishii S, Otsuka S, Senoo K (2009) Temporal shifts in diversity and quantity of nirS and nirK in a rice paddy field soil. Soil Biol Biochem 41(10):2044-2051

Yoshida M, Ishii S, Otsuka S, Senoo K (2010) nirK-harboring denitrifiers are more responsive to denitrification-inducing conditions in rice paddy soil than nirS-harboring bacteria. Microbes Environ 25(1):45-48

Zheng YM, Chen TB, He JZ (2008) Multivariate geostatistical analysis of heavy metals in topsoils from Beijing, China. J Soils Sediments 8(1):51-58

Zou J, Liu S, Qin Y, Pan G, Zhu D (2009) Sewage irrigation increased methane and nitrous oxide emissions from rice paddies in southeast China. Agric Ecosyst Environ 129(4):516-522

Zumft WG (1997) Cell biology and molecular basis of denitrification. Microbiol Mol Biol Rev 61(4):592 